\title{
Knowledge, Attitude and Practice of Students on Sexual Life (Case of the Nsilwilo Institute in Manono)
}

\author{
Martin Banza Mwana Bute1, Danny Mufite Kapya1, Jean-Luc Banze Lukanda1, \\ Faustin Kakudji Mutungula1, Bernard Nsenga Ndala1, Christine Ngoy Mwilambwe1, \\ Valeri Nkumwimba Wa Mwamba1, Tommy Mpiana Lubeji1, Dieudonné Kabulo Wa Ngoy', \\ Prosper Pamba Mazomena ${ }^{1}$, Simon Ilunga Kandolo2*
}

\footnotetext{
${ }^{1}$ Higher Institute of Medical Techniques of Manono, Manono, Tanganyika Province, Democratic Republic of Congo ${ }^{2}$ School of Public Health at the University of Lubumbashi, Lubumbashi, Democratic Republic of Congo

Email: ^silungak@gmail.com
}

How to cite this paper: Banza Mwana Bute, M., Mufite Kapya, D., Banze Lukanda, J.-L., Kakudji Mutungula, F., Nsenga Ndala, B., Ngoy Mwilambwe, C., Nkumwimba Wa Mwamba, V., Mpiana Lubeji, T., Kabulo Wa Ngoy, D., Pamba Mazomena, P. and Ilunga Kandolo, S. (2021) Knowledge, Attitude and Practice of Students on Sexual Life (Case of the Nsilwilo Institute in Manono). Open Access Library Journal, 8: e8230.

https://doi.org/10.4236/oalib.1108230

Received: November 26, 2021

Accepted: December 26, 2021

Published: December 29, 2021

Copyright $\odot 2021$ by author(s) and Open Access Library Inc.

This work is licensed under the Creative Commons Attribution International License (CC BY 4.0).

http://creativecommons.org/licenses/by/4.0/ (c) (i) Open Access

\begin{abstract}
Introduction: Premature and unwanted sex is often the basis of sexually transmitted infections and unintended pregnancies. Our objective is to contribute to the reduction of mortality as well as morbidity linked to irresponsible sexual relations, which remain a real public health problem. Methodology: We carried out a cross-sectional descriptive study involving 79 pupils in the 5th and 6th grades of the Nsilwilo school in Manono. Our sampling was exhaustive. Results: In our series, there were 79 students among whom 62 (78.5\%) declared having had sexual intercourse; Students aged between 18 and 20 were more represented (64.6\%); Male students were more represented than female students with $63.3 \%$ and $36.7 \%$ respectively. The Protestant religion was the most represented with 49 pupils among the 79 questioned, $62 \%$; the majority of students come from a two-parent union (69.6\%) followed by those from a single-parent union (21.5\%) while those from a polygamous union represent $8.9 \%$. Most students had their first sexual intercourse between the ages of 17 and 21 (50\%) while 4 students (6\%) did not specify the age of their first sexual intercourse. In $27 \%$ of cases, students had more than 5 intercourses against those who had only one. Thirty-four (34\%) of the cases had intercourse with 2 to 3 sexual partners. Conclusion: Sexuality should not be viewed as taboo in homes as much as in schools.
\end{abstract}

\section{Subject Areas}

Public Health 


\section{Keywords}

Knowledge, Attitude, Sex Life Practice, Student, Manono

\section{Introduction}

Around the world, gender norms and power differences profoundly affect the sexual attitudes, practices and health of both girls and boys. Sexuality and Relationship Education (SEE) opens a way for young people to reflect on traditional gender understandings that threaten their health, thereby laying the foundations for rewarding sex lives. However, it is unfortunate that many ESR programs, at best, only superficially address the issue of sexual norms and the valuation of critical thinking. Worse yet, in some developing countries, ESR programs do not reach the majority of girls aged 15 - 19, a large proportion of whom are simply not attending school [1].

Girls in West and Central Africa are at the highest risk of being married during their childhood: in the region, around 4 in 10 young women were married before the age of 18 , and among all married girls, one in three was married before the age of 15 . The rate of child marriage in West and Central Africa is higher than that of all other regions of the world, with six of the ten countries with the highest rates of child marriage in the region [2].

West and Central Africa have the highest percentage of sexually active girls $(36 \%)$, in the context of marriage or union for the vast majority of them (29\%), only $7 \%$ of sexually active girls are not married [3].

The uptake of sexual and reproductive health services is generally low in the region and even lower among adolescent girls, married and unmarried. This explains the high teenage birth rate of 129 live births per 1000 adolescent girls, compared to the global average of 52 live births per 1000 adolescent girls. The Central African Republic has a rate of 229, the highest in the world. The rates in Niger and Chad are over 200. Strikingly, while unmet need has declined in several countries around the world, it has increased in six WCA countries. The data available on the unmet needs of young unmarried women indicate that they are higher than those of young married women and that they are highest in Senegal, where they reach $69.5 \%$ [4].

A high teenage birth rate is also influenced by child marriage, low rate of education for girls, limited access to quality sexual and reproductive health services, as well as socio-cultural factors and economic. However, a few countries, Ghana, Liberia, Mauritania and Sierra Leone, as well as urban areas of Togo, Benin and Cameroon and rural areas of Congo, have experienced a decline of at least $10 \%$ in marriage. of children between two MICS or DHS surveys. Teenage pregnancy rate is also declining in parts of the region, including Ghana, Senegal and Liberia [5].

Education is an important tool for reducing inequalities and poverty. It lays 
the foundations for sustainable socio-economic development, equips young people with skills for employment and innovation, and enables them to make a significant contribution to societal progress. Goal 4 of the SDGs target equitable and quality primary and secondary education for boys as well as girls, as well as providing access to affordable and quality technical, vocational, and tertiary education to all women and men. However, West and Central Africa have many out-of-school children, a low primary school enrollment rate, a high pupil-to-teacher ratio, a critical gender gap in enrollment. and academic progress. These factors have a strong negative impact on the educational achievements of young people [6].

It seems to us that building actions in sexuality education based solely on the existence of a link between knowledge and behavior does not ensure their effectiveness, just like establishing an unambiguous curriculum for the content of sexuality education programs. sexuality is questionable. On the other hand, it is necessary that in school sex education projects, both the voice of the students and that of the teachers, who are the key players in this action, be taken into account [7].

By exploring sexual behavior, the demographic health survey conducted in the DRC (EDS-RDC 2014) informs us that 3\% of women aged 15 - 49 had declared having had at least two sexual partners in the last 12 months preceding the survey and of these, $12 \%$ said they had used a condom the last time they had sex [8].

In Lubumbashi, the study by Tabihta et al. (2015) showed that the frequency of sexually active adolescents is around $56.9 \%$, and the average age at first sexual intercourse is $12 \pm 2.75$ years. Faced with these socially and normally disturbing facts, research themes on the sexuality of young people have become a priority. Especially since the environment (unfavorable socioeconomic context, polygamy, single parental home) etc. in which we operate becomes more and more permissive thus leading to an increase in sexual activity among young singles. The main question of this research is to know the factors that influence the sexual behavior of young people in our environment. We believe, however, that the factors that influence the sexual behavior of young people are among others: poverty, the media, age, religion, the Internet, and the living environment.

\section{Methodology}

This study was carried out in the town of Manono. It consisted in determining the knowledge, attitudes, and practices of high school students on sexual life. The study targeted students at Nsilwilo secondary school in Manono in Tanganyika province in the Democratic Republic of Congo. The data was collected from 03/01/2021 to 04/30/2021. The pupils of the 5th and 6th grades were concerned by our study. The barrier gestures in the face of Covid19 have been scrupulously observed.

Our sampling was exhaustive, and its size is 79 students. The questionnaire and the interview were used as data collection tools which were analyzed on SPSS version 23. 


\section{Results}

Students aged between 18 and 20 were more represented (64.6\%)(Table 1).

Lukushi and Luvua wards had higher elevations (38\%) (Table 2).

Male students were more represented than female students with $63.3 \%$ and $36.7 \%$ respectively (Table 3 ).

There were more students of the Protestant religion (62\%) (Table 4).

Table 5 indicates that the majority of students come from a two-parent union (69.6\%) followed by those from a single-parent union $(21.5 \%)$ while those from a polygamous union represent $8.9 \%$.

In $78.5 \%$ of the cases, the students had already had sex against 17 students (21.5\%) who had never had sex (Table 6).

The majority of students had their first sexual intercourse between the ages of 17 and 21 (50\%) while 4 students (6\%) did not specify the age of their first sexual intercourse (Table 7).

In $27 \%$ of cases, students had more than 5 intercourses against those who had only one (Table 8).

Table 1. Distribution of respondents by age.

\begin{tabular}{ccc}
\hline Age & Frequency & percentage \\
\hline $15-17$ & 11 & 13.9 \\
$18-20$ & 51 & 64.6 \\
$21-23$ & 16 & 20.3 \\
$24-26$ & 0 & 0.0 \\
$27-29$ & 1 & 1.3 \\
Total & 79 & 100 \\
\hline
\end{tabular}

Table 2. Distribution of respondants according to the origin of the respondents.

\begin{tabular}{ccc}
\hline Province & Frequency & Percentage \\
\hline Lukushi & 30 & 38.0 \\
Luvua & 30 & 38.0 \\
Kaulu minono & 12 & 15.2 \\
Suya & 4 & 5.1 \\
Autre & 3 & 3.8 \\
Total & 79 & 100 \\
\hline
\end{tabular}

Table 3. Distribution of respondents by sex.

\begin{tabular}{ccc}
\hline Sex & Frequency & Percentage \\
\hline Male & 50 & 63.3 \\
Female & 29 & 36.7 \\
Total & 79 & 100 \\
\hline
\end{tabular}


Table 4. Distribution of respondents according to religion.

\begin{tabular}{ccc}
\hline Religion & Effectif & Pourcentage \\
\hline Catholic & 20 & 25.3 \\
Protestant & 49 & 62.0 \\
Kimbanguist & 1 & 1.3 \\
Muslim & 3 & 3.8 \\
Others & 6 & 7.6 \\
Total & 79 & 100 \\
\hline
\end{tabular}

Table 5. Distribution of students by type of parental union.

\begin{tabular}{ccc}
\hline Marital status & Frequency & Percentage \\
\hline Mono parental & 17 & 21.5 \\
Biparental & 55 & 69.6 \\
Polygame & 7 & 8.9 \\
Total & 79 & 100 \\
\hline
\end{tabular}

Table 6. Distribution of results according to sexual intercourse experience.

\begin{tabular}{ccc}
\hline Sexual intercourse & Frequency & Percentage \\
\hline Yes & 62 & 78.5 \\
No & 17 & 21.5 \\
Total & 79 & 100 \\
\hline
\end{tabular}

Table 7. Distribution of respondents according to the age of the first experience.

\begin{tabular}{ccc}
\hline $\begin{array}{c}\text { Age of their first sexual } \\
\text { intercourse }\end{array}$ & Frequency & Percentage \\
\hline $7-11$ years & 6 & 10 \\
$12-16$ years & 21 & 34 \\
$17-21$ & 31 & 50 \\
Unspecified & 4 & 6 \\
Total & 62 & 100 \\
\hline
\end{tabular}

Table 8. Distribution of respondents according to the number of times they have sex.

\begin{tabular}{ccc}
\hline Number of times & Frequency & Percentage \\
\hline 1 & 9 & 14.5 \\
$2-3$ & 21 & 33.9 \\
$4-5$ & 15 & 24.2 \\
$>5$ & 17 & 27.4 \\
Total & 62 & 100 \\
\hline
\end{tabular}


Table 9 shows that more sexual intercourse took place with the boy's friend (54.8\%) compared to only 2 (3.2\%) which took place at the hotel.

Most of the intercourse took place during the undetermined hour (45\%), 17 (27\%) students said they had sex during an unoccupied hour while $6(10 \%)$ students had sex during an unoccupied hour. had sex during recess (Table 10).

In almost $34 \%$ of cases, students have had sex with 2 to 3 sexual partners (Table 11).

Out of a total of 79 students, 41 (51.9\%) know about the existence of sexually transmitted diseases (Table 12).

Out of 62 students who have had sexual intercourse, only 21 (33.9\%) use a condom compared to 41 (66.1\%) who do not (Table 13).

In $67,7 \%$ of cases, students who have already had sex continue to have it, i.e. 42 students out of 62 (Table 14).

Table 9. Distribution of students by place of sexual encounter.

\begin{tabular}{ccc}
\hline Sexual encounter place & Frequency & Percentage \\
\hline Hotel & 2 & 3.2 \\
At the parents of the girl & 7 & 11.3 \\
In parents of boys & 14 & 22.6 \\
At the boy's friend & 34 & 54.8 \\
Other(s) to be specified & 5 & 8.1 \\
Total & $\mathbf{6 2}$ & 100 \\
\hline
\end{tabular}

Table 10. Distribution of students by time of sexual encounter.

\begin{tabular}{ccc}
\hline The time of sexual encounter & Frequency & Percentage \\
\hline After class & 11 & 17.7 \\
At break & 6 & 9.7 \\
During an unoccupied hour & 17 & 27.4 \\
Other(s) to be specified & 28 & 45.2 \\
Total & 62 & 100 \\
\hline
\end{tabular}

Table 11. Distribution of students according to the number of partners.

\begin{tabular}{ccc}
\hline Number of known partners & Frequency & Percentage \\
\hline$<1$ & 20 & 32.3 \\
$1-3$ & 21 & 33.9 \\
$4-5$ & 8 & 12.9 \\
$>5$ & 13 & 21.0 \\
Total & 62 & 100 \\
\hline
\end{tabular}


Table 12. Distribution of results according to knowledge of sexually transmitted infections (STIs).

\begin{tabular}{ccc}
\hline According to knowledge of STIs & Frequency & Percentage \\
\hline Yes & 41 & 51.9 \\
No & 38 & 48.1 \\
Total & 79 & 100 \\
\hline
\end{tabular}

Table 13. Distribution of students according to condom use at first intercourse.

\begin{tabular}{ccc}
\hline Condom use at first intercourse & Frequency & Percentage \\
\hline Yes & 21 & 33.9 \\
No & 41 & 66.1 \\
Total & 62 & 100 \\
\hline
\end{tabular}

Table 14. Breakdown of results according to the attendance of a partner.

\begin{tabular}{ccc}
\hline Attendance of a partner & Frequency & Percentage \\
\hline Yes & 42 & 67.7 \\
No & 20 & 32.3 \\
Total & 62 & 100 \\
\hline
\end{tabular}

\section{Discussion}

Out of a total of 79 students surveyed in our study, 62 declared having had sexual intercourse and therefore we have a prevalence of $78.5 \%$. This prevalence is higher than that found in Likasi (42\%) [9]. A Conakry, this prevalence is $45.2 \%$ [10].

Regarding the gender of the students, Table 3 shows that the male students were more represented than those of the female sex with respectively $63.3 \%$ and $36.7 \%$. These proportions are different from those found in Conakry where out of 226 students having ever had sex, 162 were female (71.7\%) and 64 were male (28.3\%) [10].

The Protestant religion was the most represented with 49 students among the 79 surveyed, or $62 \%$ as shown in Table 4 .

Regarding the type of union, Table 5 indicates that most students come from the two-parent union (69.6\%) followed by those from the single-parent union (21.5\%) while those from a polygamous union represent $8.9 \%$.

Most students had their first sexual intercourse between the ages of 17 and 21 (50\%), while 4 students (6\%) did not specify the age of their first sexual intercourse (Table 7). In Likasi, 38\% of schoolchildren had their first sexual intercourse between the ages of 10 and 15 [9]. In Conakry, nearly nine out of ten students who had sex had sex between the ages of 15 and 19.

Table 8 shows that in $27 \%$ of cases, students had more than 5 intercourse compared to those who had only one and, contrary to the results of Kalambay et 
al. which reports that the majority of respondents used the hotel service [11], our series shows that respondents meet at the home of the boy's friend (54.8\%). La majorité des rapports sexuels ont eu lieu pendant l'heure qui n'a pas été déterminée (45\%), 17 (27\%) élèves ont dit avoir des rapports sexuels During an unoccupied hour when 6 (10\%) students had sex during recess (Table 10).

In nearly $34 \%$ of cases, the students had intercourse with 2 to 3 sexual partners (Table 11). A Likasi Mukadi et al. found that $56 \%$ of schoolchildren had more than one sexual partner [9]. In Conakry, the majority (56.2\%) of students who have ever had sex have had it with only one sexual partner [10].

Our observation shows that out of a total of 79 students, 41 (51.9\%) are aware of the existence of sexually transmitted diseases. Our results meet those found by the Tshimanga study in which the majority of respondents have information on HIV [9].

Out of 62 students who have had sexual intercourse, only 21 (33.9\%) use a condom against 41 (66.1\%) who do not use it and 42 students (67.7\%) continue to see a sexual partner (Table 14). In Likasi, condom use is $72 \%$ while NGONGO SHAKO et al. found in their study that the prevalence of condom use was very low [12].

\section{Conclusions}

Our study focused on sexuality in schools. We observed that in $78.5 \%$ of cases, sexually active students had already had at least one sexual intercourse, only $33.9 \%$ used a condom, $67.7 \%$ continued to see a sexual partner.

Students aged between 18 and 20 were more represented (64.6\%).

Lukushi and Luvua wards had more students (38\%). It is important that the life education program is strengthened and that it is seen as a transversal program to be provided at all levels of primary and secondary education.

\section{Conflicts of Interest}

The authors declare no conflicts of interest.

\section{References}

[1] Rogow, D. and Haberland, N. (2005) L'éducation à la sexualité et aux relations : vers une approche intégrée aux études sociales. Sex Education, 5, 333-344,.

[2] Unfpa and Unicef (2018) Le mariage des enfants en Afrique de l'Ouest et du Centre.

[3] Unfpa-Unicef (2018) Le mariage desenfants en Afrique de l'ouest et du centre. https://www.unicef.org/wca/fr/rapports/le-mariage-des-enfants-en-afrique-de-loues t-et-du-centre

[4] Unfpa (2018) Rapport sur les adolescents et les jeunes : Afrique de l'Ouest et et du Centre.

[5] Cedeao, D.L.E. (2016) Analyse situationnelle de la sante des adolescents et jeunes y compris la sante sexuelle et reproductive dans l'espace CEDEAO.

https://healtheducationresources.unesco.org/library/documents/analyse-situationne lle-de-la-sante-des-adolescents-et-jeunes-y-compris-la-sante 
[6] Amg.um.dk (2018) La jeunesse en développement de la politique à la pratique. https://amg.um.dk/en/tools/youth-in-development/

[7] MiniSanté-Maroc and Unfpa (2019) Etude des Connaissances, Attitudes et Pratiques des parents et des besoins des adolescents et jeunes en matière d'éducation sexuelle et reproductive Termes de Référence.

https://morocco.unfpa.org/sites/default/files/submissions/tdr etude cap 2021.pdf

[8] MiniplanRdc (2014) Deuxième enquête démographique et de santé (EDS-RDC II 2013-2014). Rapport préliminaire, RDC.

[9] Mukadi, R.T., Ntambwe, M.S.M., Kitoko, H.T., Mwisi, J.M. and Mbayo, F.I. (2018) Sexualité des jeunes en milieu scolaire dans la ville de Likasi en République Démocratique du Congo. Pan African Medical Journal, 8688, 1-11.

[10] Diallo, A., Diallo, Y., Magassouba, A.S., Bah, I.K. and Sy, T. (2020) Rapports sexuels chez les élèves de la commune de Matoto à Conakry en Guinée Sexual intercourse among students in Matoto, Conakry, Guinea. Pan African Medical Journal, 8688, 1-9. https://doi.org/10.11604/pamj.2020.35.113.20733

[11] Banza, B.K. and Duchene, J. (2006) Sexualité des écoliers de Kinshasa: de la guerre de libération à la libération sexuelle. Nécessité d'une éducation sexuelle libérée. Colloque International "Education, violence, conflits et perspectives de paix en Afrique".

[12] Shako, M.N., Kluyskens, Y. and Kokolomami, J. (2015) Comportements sexuels à risque à Lodja, cité à haute prévalence du VIH/Sida en République Démocratique du Congo Risky sexual behaviors in a high HIV/AIDS prevalence city, Lodja case (DRC ). Annale des Sciences de la Santé, 1, 3-15. 